\title{
HUBUNGAN KEPERCAYAAN KARYAWAN PADA ORGANISASI TERHADAP KOMITMEN KEPADA ORGANISASI PADA PT. BANK X
}

\author{
Yunita Zahra* \\ Emmy Mariatin \\ Universitas Sumatera Utara \\ ABSTRAK
}

Penelitian ini mengeksaminasi peran kepercayaan karyawan kepada organisasi terhadap komitmen kepada organisasi. Hasil penelitian ini menunjukkan bahwa semakin tinggi kepercayaan karyawan kepada organisasi diikuti oleh peningkatan identifikasi dan keterlibatan pegawai terhadap organisasi (komponen affective komitmen), persepsi kerugian yang akan muncul jika meninggalkan pekerjaan (komponen continuance komitmen), dan perasaan bertanggung jawab terhadap organisasi (komponen normative). Penelitian ini menunjukkan pentingnya membangun kepercayaan karyawan terhadap organisasi terhadap komitmen karyawan kepada organisasi.

Kata kunci: Kepercayaan pada organisasi; komitmen organisasi; komitmen affective; komitmen continuance; komitmen normative

\section{THE ROLES OF EMPLOYEES' TRUST ON COMMITMENT TOWARD ORGANIZATION IN BANK X}

\begin{abstract}
The present research examines the roles of trust on employee's commitment towards organization. The results of this study showed that the enhancement of employee's trust is followed by the enhancement of employee's identification and involvement towards organization (affective component of commitment), perceived lost that would occur should one leave the organization (continuance component of commitment), and the extent of responsilibity one felt towards organization (normative component of commitment). This study demonstrated the importance of employee's trust towards organization in building employee's commitment towards organization.
\end{abstract}

Keywords: Trust towards organization; organizational commitment; affective commitment; continuance commitment; normative commitment

*Korespondensi mengenai penelitian ini dapat dilayangkan kepada Yunita Zahra, melalui email: yzahra8@gmail.com 
Era globalisasi membuat perusahaan-perusahaan di seluruh dunia bersaing antar satu dengan lainnya agar dikenal sebagaithebest employer in their industry or community. Globalisasi yang terjadi saat ini memberikan dampak yang signifikan bagi kelangsungan hidup organisasi. Tilaar (1997) menjelaskan proses globalisasi bergerak sejalan dengan tiga arena kehidupan manusia, yaitu arena ekonomi, politik, dan budaya. Dimensi ekonomi salah satunya dalam hal pasar kerja. Pada dimensi pasar kerja adanya kebebasan bergerak para pekerja. Dengan pesatnya pertumbuhan globalisasi menyebabkan terjadinya dinamika ketenagakerjaan. Dengan demikian, para tenaga kerja perlu dikelola dengan baik. Dessler (2006) menyebutkan bahwa globalisasi di bidang ekonomi dan beberapa tren lainnya merupakan pemicu perubahan bagi perusahaan dalam mengorganisasikan, mengelola dan memanfaatkan departemen personalia atau sumber daya manusia (SDM) mereka. Untuk mencapai tujuan dan mempertahankan kelangsungannya, perusahaan membutuhkan adanya komitmen organisasi dari para karyawannya yaitu hubungan yang aktif antar individu dengan perusahaannya, dimana individu bersedia memberikan sesuatu atas kehendak sendiri demi tercapainya tujuan perusahaan (Prabowo, 2000; Alwi, 2001).

Pada saat ini komitmen organisasi lebih dikenal sebagai sikap kerja yang multidimensi (Allen \& Meyer, 1997). Allen dan Meyer (dalam Cetin, 2006) meneliti komitmen organisasi dengan pendekatan multidimensional. Berdasarkan perspektif ini, hubungan psikologis antara karyawan dengan organisasinya memiliki tiga bentuk yang berbeda, yaitu affective, continuance dan normative. Komponen affective berkaitan dengan emosional, identifikasi dan keterlibatan pegawai dalam organisasi. Komponen continuance didasarkan pada persepsi pekerja tentang kerugian apabila ia meninggalkan organisasi, sedangkan komponen normative menunjukkan perasaan pegawai tentang kewajiban yang harus ia berikan kepada organisasi. Gellatly, Meyer dan Luchak (2006) mengemukakan bahwa perilaku kerja seorang karyawan tergantung dari kekuatan relatif ketiga komponen komitmen tersebut.

Faktor-faktor yang mempengaruhi komitmen individu pada organisasinya seperti yang disebutkan Steers dan Porter (dalam Yuwono, Purwanto \& Kurniawan, 2006) salah satunya mencakup perasaan terpenuhinya harapan-harapan individuterhadap organisasi. Harapan-harapan ini berkaitan dengan kepercayaan karyawan itu sendiri terhadap organisasi atau perusahaannya. Ketika karyawan memiliki kepercayaan yang tinggi terhadap organisasinya mereka akan peduli terhadap masa depan dan keberhasilan perusahaan dan memahami peran mereka dalam organisasi serta berusaha melakukan yang terbaik dari peran mereka tersebut (Boe, 2002)

Penelitian KramerdanMatthai (dalam Tezi, 2002) menemukan bahwakepercayaan organisasionaladalahprediktor yang bermakna terhadapkomitmen organisasi. Beberapa temuanmemberikanbukti bahwakepercayaan organisasiadalah elemen pentinguntukkesuksesan organisasisepertikomitmen organisasi.Dengan demikian dapatdikatakan bahwakaryawan perlumerasa yakin bahwausaha merekaakanmenghasilkanbeberapamanfaat bagidiri mereka sendiri danorganisasi (dalam Tezi, 2002). Dengan demikian, kepercayaan pada organisasi memainkan peranan penting di dalam perusahaan terutama dalam menciptakan komitmen organisasi termasuk dalam Perusahaan Perbankan.

Pertumbuhan suatu bank sangat tergantung pada pelayanan para karyawan kepada nasabah dan tingkat komitmen karyawan terhadap perusahaan. Salah satu strategi yang dikembangkan untuk mempertahankan karyawan yang kompeten adalah dengan menciptakan karyawan yang loyal dan berkomitmen pada perusahaan. Perbankan merupakan dunia bisnis yang melibatkan kepercayaan. Penelitian menemukan bahwa pelanggan itu lebih percaya terhadap karyawan (Edelman, 2006; Keller \& Berry, 2000 dalam Mishra, 2007). Sehingga awal dari kepercayaan pelanggan adalah kepercayaan karyawan itu sendiri terhadap 
kemampuan perusahaan untuk dapat memenuhi harapan. Karyawan yang sudah terpenuhi segala kebutuhannya maka akan memiliki komitmen terhadap organisasi (Mathis\& Jackson, 2001).Berdasarkan asumsi ini dan pendapat para ahli di atas, maka peneliti tertarik untuk meneliti bagaimana peran kepercayaan karyawan pada organisasi terhadap aspek-aspek komitmen organisasi di PT. Bank X. Kami berhipotesis bahwa peningkatan kepercayaan terhadap organisasi akan diiringi oleh peningkatan komponen affective (Hipotesis 1), contunuance (Hipotesis 2), dan normative (Hipotesis 3).

\section{Penelitian ini}

Meskipun cukup banyak penelitian yang menghubungkan komitmen dengan kepercayaan namun, sepengetahuan kami, belum ada penelitian, khususnya di Indonesia yang meneliti hubungan ini lebih spesifik dalam konteks kepercayaan karyawan terhadap perusahaan atau organisasi tempatnya bekerja.

\section{METODE}

\section{Partisipan penelitian}

Partisipan adalah 98 orang karyawan tetap PT. Bank X, yang telah bekerja selama minimal satu tahun.

\section{Prosedur dan alat ukur}

Untuk keperluan penelitian ini, alat ukur yang digunakan berupa kuesioner yang berisi skala-skala untuk mengukur variabel-variabel penelitian. Kuesioner ini disebarkan kepada para subjek penelitian untuk diisi. Kuesioner dikumpulkan setelah para partisipan menyelesaikan pengisian. Semua item dibuat dalam bentuk skalaempat titik ( 1 = sangat tidak sesuai -4 = sangat sesuai; sebagian aitem dikonstruksi secara terbalik). Komitmen Organisasi diukur dengan skala yang kami bangun berdasarkan teori Allen \& Meyer (1997). Skala ini terdiri atas tiga sub-skala (affective, continuance, normative). Skala affective diukur dengan 11 butir (e.g., "Saya merasa tidak nyaman bekerja di perusahaan tempat saya bekerja di saat ini", "Saya merasa menjadi bagian penting dari perusahaan ini; $\alpha=.89 ; M=3.02, S D$ $=0.49$, skewness $=-0.26$, kurtosis $=-0.13$ ). Skala continuance diukur terdiri atas lima butir (e.g., "Saya tidak takut terhadap kemungkinan yang akan terjadi apabila saya keluar dari pekerjaan saya saat ini", "Perusahaan ini adalah tempat yang tepat untuk perjalanan karier saya"; $\alpha=.69 ; M=2.92, S D=0.47$, skewness $=-0.03$, kurtosis $=0.25)$. Skala normative diukur dengan delapan butir (e.g., "Saya merasa bahwa seseorang itu tidak harus selalu loyal kepada perusahaannya", "Berpindah kerja dari satu perusahaan ke perusahaan lain bukan merupakan suatu masalah bagi saya"; $\alpha=.80 ; M=3.05, S D=0.43$, skewness $=0.19$, kurtosis $=-0.08$ ). Sedangkan Kepercayaan pada Organisasi diukur dengan skala berdasarkan teori (Zalabak, Morreale \& Hackman, 2010). Skala ini berjumlah 67 item (e.g., "Perusahaan membuat kebijakan tanpa meminta pendapat para karyawannya"; $\alpha=.98 ; M=2.94, S D=$ 0.41 , skewness $=0.04$, kurtosis $=0.23$ ).

\section{HASIL}

Kami berhipotesis bahwa semakin tinggi kepercayaan karyawan pada organisasi, maka semakin tinggi komitmen affective (Hipotesis 1), continuance (Hipotesis 2), dan normative (Hipotesis 3). Hipotesis ini kami ujikan dengan analisis korelasi pearson. Sesuai dengan yang dihipotesiskan, kepercayaan karyawan pada organisasi berhubungan searah dengan komitmen affective ( $r=.77, p=.001)$, continuance $(r=.69, p=.001)$, dan normative $(r=.77, p=.001)$. Secara spesifik, dengan mempertimbangkan effect size $\left(r^{2}\right)$, maka sebanyak 59\% kebervariasian komitmen affective, 48\% continuance, dan 59\% normative dapat dijelaskan oleh kepercayaan terhadap organisasi. Dengan demikian, sesuai dengan 
Hipotesis 1, 2, dan 3, semakin tinggi kepercayaan karyawan pada organisasi, semakin tinggi komitmen affective, continuance, dan normative para karyawanterhadap perusahaan.

\section{DISKUSI}

Hasil penelitian menunjukkan bahwa kepercayaan pada organisasi berhubungan positif yang cukup kuat dengan komitmen affective. Sumbangan efektif kepercayaan pada organisasi terhadap komitmen affective karyawan sebesar 59\%. Ada beberapa alasan yang menyebabkan hubungan positif antara kepercayaan pada organisasi dengan komitmen affective. Pertama, karyawan merasa telah dilibatkan dalam organisasi sehingga mereka juga merasa memiliki kelekatan emosi dan menjadi bagian dari organisasi akibatnya mereka terus ikut terlibat aktif untuk keberhasilan organisasi. Hal ini sesuai dengan kesimpulan dari Coetzee (2005) yang menyatakan bahwa jika karyawan yakin pada nilai partisipasi organisasi, mereka akan lebih merasakan bahwa partisipasi mereka akan membuat suatu perbedaan. Konsekuensinya, mereka akan lebih bersedia untuk mencari solusi dan membuat saran untuk kesuksesan suatu organisasi.Kedua, karyawan percaya bahwa perusahaan akan bertindak untuk kepentingan mereka. Hal ini sesuai dengan hasil penelitian yang menyimpulkan bahwa persepsi karyawan akan keadilan dari kebijakan yang dibuat perusahaan berhubungan secara signifikan dengan komitmen affective (Allen \& Meyer, 1997).Ketiga, karyawan yang merasa bahwa organisasi ataupun pimpinan peduli terhadap mereka akan menimbulkan kepercayaan dan mengarahkan pada komitmen mereka. Allen dan Meyer (1997) menyatakan bahwa secara umum karyawan memiliki komitmen affective yang lebih kuat ketika pimpinan mereka mengizinkan mereka untuk ikut berpartisipasi dalam pengambilan keputusan.

Selanjutnya, dapat dilihat juga bahwa kepercayaan pada organisasi berhubungan positif yang cukup kuat dengan komitmen continuance. Sumbangan efektif kepercayaan pada organisasi terhadap komitmen continuance karyawan sebesar 48\%. Dari hasil analisa tersebut maka hipotesa yang menyatakan korelasi antara kepercayaan pada organisasi dengan komitmen continuance dapat diterima. Korelasi ini,merujuk pada Moore (1998) dapat terjadi karena kepercayaan merupakan keyakinan dalam diri atau kepercayaan dalam kerjasama dengan pihak lain dalam memberikan suatu hasil yang dinginkan di masa akan datang. Adanya keyakinan karyawan bahwa perusahaan akan memberi keuntungan bagi mereka menyebabkan mereka menyadari akan kerugian bila meninggalkan organisasi.

Begitu juga hubungan kepercayaan pada organisasi dengan komponen komitmen normative karyawan. Berdasarkan hasil penelitian menunjukkan bahwa kepercayaan karyawan pada organisasi berhubungan positif yang cukup kuat dengan komitmen normative, Sumbangan efektif kepercayaan pada organisasi terhadap komitmen normative karyawan sebesar 59\%. Alasan yang menyebabkan hubungan positif ini, yaitu: Karyawan meyakini bahwa perusahaan telah memberikan yang terbaik sehingga mereka merasa memiliki kewajiban untuk memberikan yang terbaik pula. Oleh sebab itu, mereka memberikan energi dan usaha maksimumnya untuk perusahaan. Seperti beberapa hasil penelitian yang menunjukkan bahwa seseorang merasa memiliki kewajiban akan mencerminkanperasaan bahwaseseorang tersebut telah berhutang untuk memberikan energidan usaha maksimumnya (Eisenberger, Armeli, Rexwinkel, Lynch, \&Rhoades dalam Colquitt, et. al 2007).

Cummings dan Bromiley (dalam Kramer \& Tyler, 1996) mengemukakan bahwa keyakinan seorang terhadap pihak lain akan berpengaruh dengan komitmen orang tersebut. Hal ini menunjukkan bahwa rasa percaya dari karyawan akan mengarah padakomitmen. Kramer \& Goldman menekankan suatu pernyataan bahwa komitmen merupakan refleksi dari perilaku mempercayai(dalam Kramer \& Tyler, 1996). Hasil penelitian Mishra (2007) menyatakan bahwa perasaaan percaya dan komitmen akan mengarah kepada reputasi positif perusahaan, sebagaimana karyawan merasa senang karena dipekerjakan oleh perusahaan 
tersebut. Selanjutnya mereka akan membagikan perasaan positif tersebut kepada pelanggan dan stakeholder.

Selanjutnya, peneliti menyadari berbagai kekurangan dari penelitian ini. Penelitian ini merupakan penelitian yang menggunakan sampel tidak besar dan dilakukan pada sebuah organisasi saja. Penelitian masa depan diharapkan dapat menggunakan sampel yang lebih besar baik dari berbagai bank ataupun berbagai wilayah agar hasil penelitian dapat digeneralisasikan lebih meluas. Peneliti selanjutnya yang ingin melakukan penelitian sejenis dapat melakukan perbandingan pada beberapa perusahaan yang berbeda tidak hanya dari perusahaan perbankan guna memperkaya hasil kajian.

Terakhir, penelitian masa depan hendaknya dapat menggunakan teknik kualitatifkuantitatif dalam pengumpulan data. Teknik kuantitatif melalui kuesioner telah dilakukan pada penelitian ini, penelitian selanjutnya secara kualitatif hendaknya dapat menggunakan metode wawancara untuk memperoleh pamahaman yang lebih komprehensif dari fenomena yang terjadi mengingat setiap individu bisa memiliki pengalaman subjektif yang berbeda.

\section{REFERENSI}

Allen, N. J., \& Meyer, J. P. (1997). Commitment in the workplace. theori, research and application. Sage Publication

Alwi, S (2001). Manajemen sumber day manusia: Strategi keunggulan kompetitif.Yogyakarta: Pustaka Pelajar.

Boe, T. A (2002). Gaining and/or maintaining employee trust within service organizations. Submitted in Partial Fulfillment of the Requirements for the Master of Science Degree in Training and Development. University of Wisconsin-Stout.

Cetin, M. O. (2006). The relationship between job satisfaction, occupational and organizational commitment of academics. Journal of American Academy of Business, $8(1), 78-88$.

Coetzee, M. (2005). The fairness of affirmative action: An organisational justice perspective. University of Pretoria.http://upetd.up.ac.za/thesis/available/etd-04132005130647/unrestricted/05chapter5.pdf.

Colquitt, J. A, Scott, B. A, \& LePine J. A (2007). Trust, trustworthiness, and trust propensity: a meta-analytic test of their unique relationships with risk taking and job performance. Journal of Applied Psychology, 92(4), 909-927.

Dessler, G. (2006).Manajemen sumber daya manusia. Edisi ke-10, Alih bahasa, Jilid 1. PT. Index: Jakarta.

Gellatly, I. R., Meyer, J. P., \& Luchak, A. A. (2006). Combined effects of the three commitment components on focal and discretionary behaviours: A test of Meyer and Herscovitch's propositions. Journal of Vocational Behavior, 69, 331-345.

Kramer, R. M., \& Tyler, T.R. (1996). Trust in organizations: Frontiers of theory and research. California: Sage Publications.

Mathis, R. L., \& J.H. Jackson. (2001).Manajemen sumber daya manusia, buku 1 dan buku 2, Terjemahan, Salemba Empat, Jakarta.

Mishra, K. E (2007). Internal communication: building trust, commitment, and a Positive reputation through relationship management with Employees. A dissertation submitted to the faculty of the University of North Carolina. University of North Carolina.

Moore, K. R. (1998), Trust and relationship commitment in logistics alliances: A buyer perspective. International Journal of Purchasing and Materials, 25-37. 
Prabowo, S. (2000). Mengapa Seseorang Bertahan dalam Organisasi. Psikodemensia Kajian Ilmiah Psikologi, 11(2), 111-117.

Tezi, Y. L. (2002). The Relationship between the variables of organizational trust, job engagement, organizational commitment, and Job Involvement. Marmara Universitesi. diakses melalui http://www.belgeler.com/blg/158x/the-relationship-between-thevariables-of-organizational-trust-job-engagement-organizational-commitment-and-jobinvolvement-orgute-guven-ise-cezbolma-orgute-baglilik-ve-ise-adanmislik-arasindakiiliskilerin-incelenmesi

Tilaar, H.A.R. (1997).Pengembangan sumber daya manusia dalam era globalisasi. Grasindo: Jakarta

Yuwono, S, Purwanto, Y \& Kurniawan, A (2006). Hubungan antara persepsi manajemen lini terhadap turnover di manajemen puncak dengan komitmen organisasi. Jurnal Siasat Bisnis, 11(2), 181-188. 